\title{
THE CASE FOR ACCRETION OF THE TECTOSPHERE BY BUOYANT SUBDUCTION
}

\author{
Dallas Abbott \\ Lamont-Doherty Geological Observatory of Columbia University
}

\begin{abstract}
This paper tests three hypotheses for the origin of the tectosphere. Continental collision cannot explain the low metamorphic grade of crust that predates the tectosphere. Halfspace cooling and buoyant underplating can both fit the diamond age data, although underplating by buoyant subduction is the favored model. Thermal models provide a further test. If halfspace cooling formed the tectosphere, diamonds from $150 \mathrm{~km}$ depth will be at least $200 \mathrm{~m} . \mathrm{y}$. younger than diamonds from $190 \mathrm{~km}$. If buoyant subduction formed the tectosphere, diamonds from $150 \mathrm{~km}$ depth will be the same age or older than diamonds from $190 \mathrm{~km}$.
\end{abstract}

\section{Introduction}

The term 'tectosphere', which formerly applied to all continental lithosphere, more recently is restricted to the seismically fast, cold (meaning that diamond is stable), and thick ( $\geq 200-400 \mathrm{~km}$ ) continental lithosphere [Jordan, 1978; Lemer-Lam and Jordan, 1987]. Most crustal basement overlying the tectosphere is Archean $(\geq 2.5 \mathrm{Ga})$ in age. The youngest known crust underlain by tectosphere (as defined by diamond stability) is dated at 1.6 to $1.9 \mathrm{Ga}$ from lower crustal zircons [Reichenbach and Parrish, 1988]. The tectospheric mantle is also ancient. Age dates of inclusions in diamonds from the Kimberly and Finsch pipes on the Kaapvaal craton in South Africa range from 3.1 to $3.4 \mathrm{Ga}$ [Richardson et al., 1984]. The tectospheric mantle is chemically distinct from present day suboceanic mantle, and contains refractory peridotites depleted by the extraction of komatiitic magmas [Boyd, 1987]. As a result, tectospheric mantle melts at a higher temperature than oceanic mantle.

Diffusion is the major form of heat transport in the tectosphere. The equilibrium geotherm is thus controlled by lithospheric thickness, heat production, and basal (athenospheric) temperature. Because mantle heat production is small, unusually low mantle geotherms are typically associated with unusually thick tectosphere.

A successful model of lithospheric evolution must solve two important problems: how the tectosphere formed during the early preCambrian; and why that formation subsequently stopped. Three models are extant. The 'collision model' proposes that the tectosphere formed by shortening of formerly thin lithosphere [Jordan, 1978], much like the way that the India-Eurasia collision produced thick crust in Tibet. Because continents can collide soon after being formed, this model can explain the relatively short ( $<300$ m.y.) time difference between formation of crust and stabilization of diamonds. The strain produced by the shortening can also cause a preferred orientation in mantle minerals (as evidenced by seismic anisotropy), which is found within the Superior Province tectosphere [Silver and Chan, 1988]. The 'plum pudding model' asserts that the tectosphere accreted by adding pieces ('plums') of refractory asthenosphere to its base [Ringwood, 1989]. The plums cannot originate locally, because the overlying crust does not have enough komatiites [Takahashi, 1990]. The plums must come from elsewhere (perhaps distant subducting slabs, after a long trip through the deep mantle). Finally, the 'buoyant subduction model'

Copyright 1991 by the American Geophysical Union

Paper number 91GL00813

0094-8534/91/91GL-00813\$03.00 asserts that the tectosphere accreted by basal addition of oceanic plates during buoyant subduction at nearby trenches.

\section{The Importance of Diamond Data}

Shallow $(\sim 150 \mathrm{~km})$ diamonds form only where the tectospheric mantle is very cold, while deep $(\sim 200 \mathrm{~km})$ diamonds form at many geotherms. This pattern is due to the very steep slope of the diamond to graphite phase change, about $\sim 40^{\circ} \mathrm{C} / \mathrm{kbar}$ [Kennedy and Kennedy, 1976], in contrast to 20 to $30^{\circ} \mathrm{C} / \mathrm{kbar}$ for typical tectospheric mantle geotherms. The Archean ages of the diamonds [Richardson et al., 1984] that sample the Kaapvaal cratonic mantle from 150 to $200 \mathrm{~km}$ depth, implies that the shallow tectosphere was already cold in the Archean. The low geotherm also indicates that the tectosphere was more than $200 \mathrm{~km}$ thick.

\section{Continental Collision Model Predicts Too Many Granulites}

The shortening caused by a continental collision can double a typical $40 \pm 10 \mathrm{~km}$ crustal thickness [McLennan and Taylor, 1985]. For example, the present day Himalayan collision has thickened the Tibetan crust to nearly $75 \mathrm{~km}$ [Shackleton et al., 1988]. Once collision ceases, isostatic uplift and erosion occur; producing surface rocks that experienced deep burial and maximum pressures around 10 to $17 \mathrm{~kb}$. The petrology of these rocks reflects this burial history, and is particularly sensitive to the pressure at the point of maximum temperature (which generally occurs at a pressure somewhat lower than the maximum pressure).

Pressure-Temperature (P-T) paths that end at the surface can be tested against surficial rocks, and paths that end at depth can be tested against lower crustal xenoliths. England and Thompson [1984] have identified nine likely suites of paths. Four suites of paths pass through the blueschisteclogite field, and result in eclogitic surface rocks. Three sets of paths remain in the blueschist-eclogite field during uplift, and result in either eclogites or blueschists. The absence of any known Archean blueschists or Archean crustal eclogites [Carswell and Cuthbert, 1986; Liou et al, $1990]$ implies that these seven paths are unlikely. The remaining two groups of P-T paths have maximum pressures that are about $130 \%$ of the pressure at maximum temperature. Lower crustal xenoliths (which include Archean age amphibolites) entrained in the Kimberly pipe record pressures of at most $10 \mathrm{~kb}$ [Calsteren et al., 1986], which indicates that the maximum pressure that they experienced was only $13 \mathrm{~kb}$ (130\% higher). However during a continental collision, the lower crust is at pressures of 15 to $25 \mathrm{~kb}$. The absence of high pressure xenoliths (including granulites) rules out these two groups of P-T paths. In general, granulite facies xenoliths are quite rare on the Archean Kaapvaal craton compared to younger marginal (Himalayan-style-collisional) belts [Calsteren et al., 1986]. Based on this, the Archean crust containing the Kimberly pipe was not thickened by continental collision. Since the tectosphere in this region is also Archean in age ( $3410 \pm 80$ my [Richardson et al., 1984]), it was not produced by collision either.

\section{Continental Collisions Produce Too Little Coesite}

The lack of preserved tectosphere in Phanerozoic continental collision zones has been attributed to a decrease in mantle temperature since the Archean. The temperature decrease implies that a smaller amount of partial melting, and 
hence depletion, occurs in the Phanerozoic mantle. As a result, the Phanerozoic mantle is less buoyant than in the Archean, and it shears off and sinks instead of forming tectosphere [Ashwal and Burke, 1989].

However, even if the thickened lithosphere breaks off, it can affect the metamorphic petrology of the suture zone crust. The geothermal gradient at the suture will temporarily decrease, commonly causing the formation of blueschists or blueschist facies eclogites on the upper plate [England and Thompson, 1984]. (In contrast, most Phanerozoic blueschists form in melanges on the lower plate.) Furthermore, some of the lower plate should reach depths of $100 \mathrm{~km}$, in which case coesite will be stable. However, neither upper plate blueschists nor lower plate coesite are found at Phanerozoic sutures in which both plates lack pre-existing tectosphere (that is, both plates are younger than $1.6 \mathrm{Ga}$ ). All known crustal coesite is in three sutures: at the edge of the Baltic shield, the Yangtze craton, and in southeastern France [Wang et al., 1989]. All these coesite-bearing sutures include pre-1.6 Ga basement [Choubert et al.,1976] and presumably had a tectosphere before the collision. The only unequivocal Precambrian blueschists may also be upper plate blueschists: the circa $700 \mathrm{~m}$.y. Aksu blueschist at the edge of the Archean Tarim block and the 600-850 m.y. blueschist at the edge of the Archean-Early Proterozoic West African craton [Liou et al., 1990, Abbott and Menke, 1990]. Both blueschists are within passive margin sequences and exhibit moderate (e.g.crustal-doubling-type) metamorphic pressures. Thus, the evidence from suture zone metamorphism does not support lithospheric doubling during continental collisions.

\section{Can Top-Down Cooling Make Tectosphere Fast Enough?}

The oldest rocks on the Kaapvaal craton are 3.644 \pm .004 $\mathrm{Ga}$ [Kroner et al., 1989]. The diamonds from the Kaapvaal cratonic mantle are 3.3 $\pm 0.1 \mathrm{Ga}$ [Richardson et al., 1984]. To be successful, the plum pudding model should allow the lithosphere to cool to temperatures low enough for diamond stability within $0.34 \pm 0.1 \mathrm{Ga}$. The plum pudding model cools from the top down, with all heat being removed from the lithosphere by conduction. It can therefore cool no faster than a cooling halfspace, because the mantle upwelling which brings the plums of refractory mantle to the tectospheric base also brings more heat and retards cooling. The two critical parameters for modelling halfspace cooling are the thermal diffusivity of peridotite $\left(0.75 \times 10^{-6} \mathrm{~m}^{2} / \mathrm{s}\right.$ [Roy et al., 1989]) and the temperature of the Archean asthenosphere. Estimates of Archean mantle temperature range from $200^{\circ} \mathrm{C}$ (potential temperature $1480^{\circ} \mathrm{C}$ ) to $600^{\circ} \mathrm{C}$ hotter than at present [Elthon, 1986; Nisbet, 1987]. Because of this uncertainty, I examined the cooling history for a suite of mantles.

The halfspace cooling models (Figure 1) predict that the oldest diamonds from $150 \mathrm{~km}$ depth are 350 to $650 \mathrm{~m} . \mathrm{y}$. younger than the oldest crustal rocks. Furthermore, the crystallization ages of the oldest diamonds from $150 \mathrm{~km}$ depth are at least $200 \mathrm{~m}$.y. younger than the ages of the diamonds from $190 \mathrm{~km}$ depth. (Even though the halfspace cools from the top down, diamond becomes stable from the bottom up, due to the steep slope of the diamond stability curve). These results are consistent with the Kaapvaal data (crustal rocks, $3.6 \mathrm{Ga}$, diamond ages $3.3 \mathrm{Ga}$ ) only if the asthenosphere was at $1480^{\circ} \mathrm{C}$. Finally, the models predict that the oldest diamonds are at greater depths, with an age range of $0.3 \mathrm{Ga}$. This variation has not been reported. Nevertheless, some caution is in order: the diamond inclusion ages are model ages and their errors may be larger than the reported errors of $0.1 \mathrm{Ga}$.

Hotspots heat the base of the lithosphere, slow its cooling with time, and hence cast further doubt on the ability of the plum pudding model to satisfy the age data. At present, oceanic plates older than about $80 \mathrm{~m}$.y. are shallower and hotter than the top of a cooling halfspace. The best explanation for this is that older oceanic plates are thermally
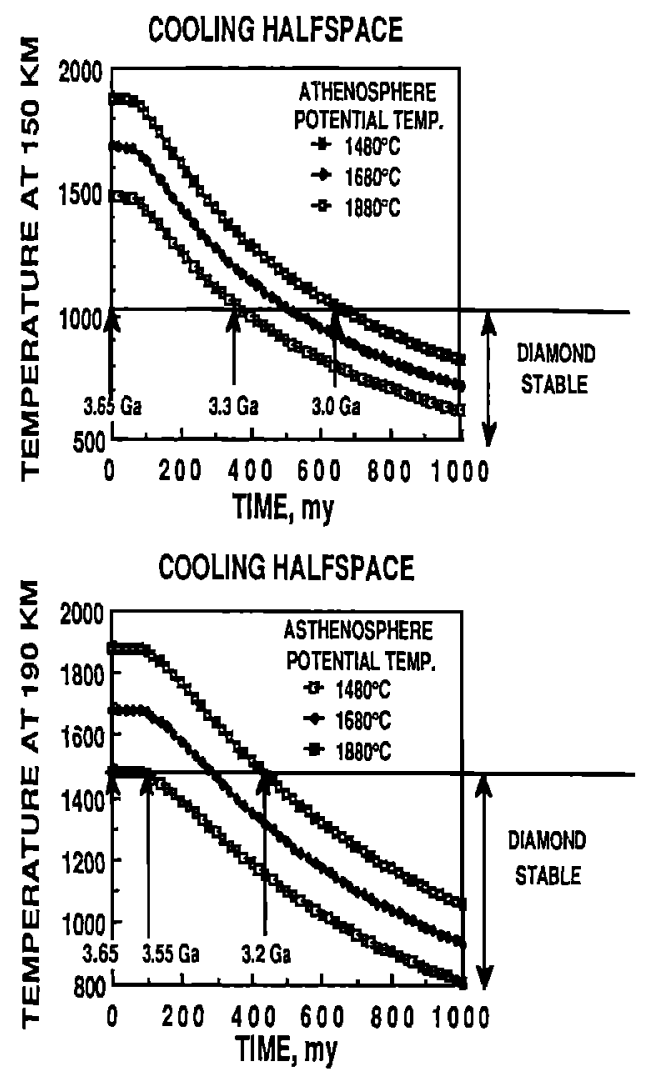

Fig. 1. Temperature v.s time in m.y. in a cooling halfspace. Arrows: start of diamond crystallization after crustal formation at $3.65 \mathrm{Ga}$. Top: at $150 \mathrm{~km}$. Bottom: at $190 \mathrm{~km}$.

rejuvenated by passing hotspots; this prevents oceanic plates from growing thicker than 100 to $125 \mathrm{~km}$ [Crough, 1978]. Although they are more difficult to detect, hotspots are also present beneath continents. Subcontinental hotspots also produce thermal rejuvenation of any lithosphere that is not too depleted to melt. Modelling of lithospheric flexure indicates that the maximum elastic thickness of post- $1.6 \mathrm{Ga}$ continental lithosphere is no greater than $44 \mathrm{~km}$; the same as that of the oldest oceanic lithosphere [Watts et al., 1982; Smith et al., 1989]. Based on this data, hotspots are equally abundant beneath continents and oceans.

The existence of Archean hotspots, particularly at the time of diamond formation beneath the Kaapvaal craton (circa 3.1-3.4 Ga) is controversial. Mafic dike swarms as old as $2.5 \mathrm{Ga}$ are comparable in surface area and age distribution to Phanerozoic dike swarms formed during hotspot initiation [Abbott, 1989]. Plateau basalts as old as $3.0 \mathrm{Ga}$ exhibit trace element chemistry like that of present day flood basalts formed by hotspots [Myers et al., 1987]. Finally, recent work indicates that komatiites may represent hotspot lavas [Campbell et al., 1989], in which case hotspots were present at $3.5 \mathrm{Ga}$. Nevertheless, because of the small area of preserved pre-3.0 Ga basement, it is difficult to be sure that this basement represents the average pre-3.0 Ga Earth. Archean hotspots could have been much less abundant at 3.1-3.4 Ga than at present.

\section{Can Plums Produce Enough Heterogeneity?}

The plum pudding model asserts that pieces of subducted plates (the plums) have passed through the lower mantle. This trip takes a long time. Archean subduction rates were similar to or slightly slower than those at present [Abbott and Menke, 1990], implying that a sinking Archean plate needed at least $23 \mathrm{~m}$.y. to reach the base of the lower mantle (at 12 $\mathrm{cm} / \mathrm{yr}$ ). The trip up is unlikely to be faster than the strongest 
Phanerozoic hotspot plume, which has a total rise time of 100 m.y. [Sleep et al., 1988]. Thus, the plums' minimum residence time is $120 \mathrm{~m}$.y. Because early Archean plates were $\leq 60 \mathrm{~m}$.y. at subduction [Bickle,1978]; they would equilibrate thermally with the surrounding mantle in less than 10 m.y. (see Molnar et al.[1979]). As a result, an Archean plate could not preserve large thermal or chemical heterogeneities if it was carried through the deep mantle. Nevertheless, there are major heterogeneities in the tectosphere.

The tectosphere contains two major suites of peridotites with non-equilibrium compositions: $\mathrm{Ca}$ rich peridotites (green-garnet bearing wehrlites) and $\mathrm{Ca}$ poor peridotites (diamondiferous low-Ca garnet harzburgites). The latter are difficult to produce metasomatically and are probably serpentinized peridotites, e.g. primary compositions [Schulze, 1986]. Extended heating of non-equilibrium peridotites changes their composition. Thus, it is difficult to explain the observed chemical diversity by a tectosphere formed from well-heated 'plums'.

Because rates of chemical diffusion are much slower than rates of thermal diffusion, it is even more difficult to preserve thermal heterogeneities. Assuming a minimum depth of origin of $150 \mathrm{~km}$, some diamond inclusions formed at temperatures $150^{\circ} \mathrm{C}$ cooler than the maximum crystallization temperature [Boyd et al., 1985]. The plum pudding model implies that all diamonds cooled directly from asthenospheric temperatures. Diamonds from $150 \mathrm{~km}$ that are $150^{\circ} \mathrm{C}$ cooler than is necessary for stability require that their parent rock was in the asthenosphere for less than $10 \mathrm{~m} . \mathrm{y}$. Thus, it is difficult to explain the temperature variability with a cooling halfspace model.

\section{Buoyantly Subducted Imbricated Slabs}

The last model proposes that the tectosphere was constructed of buoyantly subducted imbricated slabs. Three lines of evidence imply that portions of the tectosphere originally formed at mid-ocean ridges: 1) The behavior of the isotopic systems in mantle eclogites can be explained together by only one hypothesis, subseafloor hydrothermal alteration [MacGregor and Manton, 1986]; 2) The occurence of coesite throughout the entire range of composition of mantle-derived eclogites implies that the parental basalt crystallized at crustal depths and is inconsistent with mantle fractionation [Schulze and Helmstaedt, 1988] and; 3) Subseafloor hydrothermal alteration rather than mantle metasomatism is the most likely source of the carbon in diamond [Schulze, 1986]. However, the method of emplacement of the oceanic plates is more controversial.

Buoyant subduction puts subducting slabs directly onto the base of the continental lithosphere. Buoyant subduction as a way of forming thicker continental lithosphere is not a new idea [Helmstaedt and Doig, 1975; Helmstaedt and Schulze, 1989]. However, despite the evidence for buoyant underplating of continental plates in the Phanerozoic [Bird, 1988 ], buoyant subduction is not widely accepted among geophysicists as a viable method of forming the tectosphere. The following text summarizes the case for buoyant subduction in a geophysical context and proposes some thermally based age tests that could help to resolve the issue.

In the Phanerozoic, buoyant subduction occurs in locations with young lithosphere and/or thick crust [Sacks, 1984]. Thick crust forms due to higher temperatures in the mantle, which cause more melting and more depletion [Bickle, 1986]. Regions with thick crust are buoyant for two reasons: basalt is more buoyant than mantle and more depleted mantle has less garnet than less depleted mantle. Buoyancy derived from basalt is temporary; it disappears when basalt transforms to eclogite. Because garnet is a high pressure mineral, depleted mantle remains buoyant at high pressures. In the Phanerozoic, much buoyant subduction is temporary, in which case the subduction zone is first flat, and then steepens as the basalt layer changes to eclogite
[Sacks, 1984]. However, if the subducting crust is young and hot enough, it will melt [Abbott and Hoffman, 1984; Defant and Drummond, 1990], and there will be little or no dense eclogitic garnet to counteract the positive buoyancy of the depleted mantle. In the latter case, subduction remains flat and and the subducted slab thickens the continental plate.

In the Archean, hotter mantle simultaneously caused the production of more thick oceanic crust and more young oceanic plates [Bickle, 1978; 1986; Abbott and Menke, 1990]. Thicker crust and younger plates both increase the probability of melting the basaltic carapace of subducting slabs. Hotter mantle temperatures also increase the depletion of the oceanic lithospheric mantle. Thus, in the Archean, flat subduction of permanently buoyant slabs should have been much more common than at present.

Abundant buoyant subduction can also explain some other aspects of Archean tectonics. More common buoyant subduction explains the paucity of early Archean potassic granites [Abbott and Hoffman, 1984], which are produced by steep, Andean type subduction. Abundant buoyant subduction resolves the apparent paradox of the formation of the tectosphere, e.g. thicker continental plates formed when the Earths' mantle was hotter than at present. Buoyant subduction of oceanic lithosphere protects the base of the continental lithosphere from thermal erosion by the hotter Archean mantle and allows the tectosphere to thicken rapidly.

One test of the buoyant subduction model is to calculate how quickly it could form a $200 \mathrm{~km}$ thick continental lithospheric plate. Based on Bickle [1978], the average thickness of Archean oceanic plates was about $40 \mathrm{~km}$. The frequency of underplating depends on the time between trench jumps, which must be estimated from Phanerozoic data. In parts of Japan, there are five paralell blueschist belts, the oldest of which is 350-400 million years old [Banno, 1986]. Counting the present trench, this implies one trench jump every 70-80 million years. This timing of trench jumps could produce a $200 \mathrm{~km}$ thick lithosphere from an original 40 $\mathrm{km}$ thick plate in 280-320 million years; this is within the time limit derived from the diamond age dates.

Although buoyant subduction can (with some assumptions) fit the diamond ages, the most important test is simply the relative ages of the shallower diamonds compared to the deeper diamonds. If buoyant subduction is the main method of formation of the tectosphere, the shallower diamonds should be the same age or older than the deeper diamonds (opposite the prediction of the plum-pudding model, in which the shallower diamonds are younger).

\section{Conclusions}

Continental collisions do not thicken the lithospheric mantle and can not form a tectosphere. Tectosphere formed by buoyantly subducted slabs can explain the variability in shallow diamond formation temperatures and the paucity of early Archean potassic granites. Nevertheless, both buoyant subduction and halfspace cooling can fit the age dates from the Kaapvaal craton. Thermal models suggest a further test. If halfspace cooling formed the tectosphere, diamonds from $150 \mathrm{~km}$ depth will be at least $200 \mathrm{~m}$.y. younger than diamonds from $190 \mathrm{~km}$. If buoyant subduction formed the tectosphere, diamonds from $150 \mathrm{~km}$ depth will be the same age or older than diamonds from $190 \mathrm{~km}$.

Acknowledgements. I thank P. Hoffman and W. Menke for comments. This work supported by N00014-87-K-204 and EAR87-96171. L.D.G.O. Contribution No. 4753.

\section{Bibliography}

Abbott, D.H., and S.E. Hoffman, Archean plate tectonics revisited-Part I: Heat flow, spreading rate, and the age of the subducting oceanic lithosphere, and their effects on the origin and evolution of continents, Tectonics, 3 , 429-448, 1984. 
Abbott, D.H., and W.H. Menke, Length of the global plate boundary at $2.4 \mathrm{Ga}$, Geology, 18, 58-61, 1990.

Abbott, D.H., Evidence for Archean and Proterozoic hotspots, EOS Trans AGU, 70, 479, 1989.

Ashwal, L. and K. Burke, African lithospheric structure, volcanism, and topography, Earth Planet. Sci. Lett. 96, 8-14, 1989.

Banno, S., The high pressure metamorphic belts of Japan: A review, in Blueschists and Eclogites, pp.365-369, G.S.A. Mem. 164, 1986.

Bickle, M.J., Heat loss from the earth: A constraint on Archean tectonics from the relation between geothermal gradients and the rate of plate production, Earth Planet. Sci. Lett, 40, 301-315, 1978 .

Bickle, M.J., Implications of melting for stabilization of the lithosphere and heat loss in the Archean: Earth Planet. Sci. Lett., 80, 314-324, 1986.

Bird, P., Formation of the Rocky Mountains, Western United States: A continuum computer model: Science, 239, 1501-1507, 1988.

Boyd, F.R., J. J. Gurney, and S.H. Richardson, Evidence for a 150-200 km thick Archean lithosphere from diamond inclusion thermobarometry, Nature, 315, 387-389, 1985.

Boyd, F.R., High and low temperature gamet peridotite xenoliths and their possible relation to the lithosphereasthenosphere boundary beneath southern Africa, in Mantle Xenoliths, edited by P.H. Nixon, pp. 403-412, John Wiley, Chichester, 1987.

Calsteren, P.W.C., N.B.W. Harris, C.J. Hawkesworth, M.A. Menzies, and N.W. Rogers, Xenoliths from southern Africa: A perspective on the lower crust, in The Nature of the Lower Continental Crust, Blackwell, Oxford, pp. 351-362, 1986.

Campbell, I.H., R.W. Griffiths, and R.I. Hill, Melting in an Archean mantle plume: heads it's basalts, tails it's komatiites, Nature, 339, 697-699, 1989.

Carswell, D.A., and S.J. Cuthbert, Eclogite facies metamorphism in the lower continental crust, in The Nature of the Lower Continental Crust, pp.193-209, Blackwell, Oxford, 1986.

Choubert, G., A. Faure Muret and P. Chanteux, Atlas Geologique du Monde, UNESCO, Paris, 1976.

Crough, S.T., Thermal origin of mid-plate hotspot swells, Geophys. J. R. Astr. Soc., 55, 451-469, 1978.

Defant, M.J., and M.S. Drummond, Derivation of some modern arc magmas by melting of young subducted lithosphere, Nature, 347, 662-665, 1990.

Elthon, D., Komatiite genesis in the Archean mantle, with implications for the tectonics of Archean greenstone belts, L.P. I. Tech. Rept. 86-10, pp. 97-99, 1986.

England, P.C., and A.B. Thompson, Pressure-temperaturetime paths of regional metamorphism I. Heat transfer during the evolution of regions of thickened continental crust, J. Petrol., 25, 894-928, 1984.

Helmstaedt, H., and R. Doig, Eclogite nodules from kimberlite pipes of the Colorado plateau-samples of subducted Franciscan-type oceanic lithosphere, Phys. Chem. Earth, 9, 95-112, 1975.

Helmstaedt, H., and D. J. Schulze, Southern African kimberlites and their mantle sample: implications for Archean tectonics and lithosphere evolution, in Kimberlites and Related Rocks, pp. 358-368, Blackwell, Carlton, 1989.

Jordan, T.H., Composition and development of the continental tectosphere, Nature, 274, 544-548, 1978.

Kennedy, C.S., and G.C. Kennedy, The equilibrium boundary between graphite and diamond, J. Geophys. Res., 81, 2467-2470, 1976.

Kroner, A., W. Compston, and I. S. Williams, Growth of early Archean crust in the Ancient Gneiss complex of Swaziland as revealed by single zircon dating, Tectonophysics, 161, 271-298, 1989.

Lerner-Lam, A.L., and T. H. Jordon, How thick are the continents?, J. Geophys. Res., 14, 007-14,040, 1987.

Liou, J.G., S. Maruyama, X. Wang, and S. Graham, Precambrain blueschist terranes of the world, Tectonophysics, 181, 97-11, 1990.

MacGregor, I. D., and W.I. Manton, Roberts Victor eclogites: ancient oceanic crust, J. Geophys. Res., 91, 14, 063-14, 079, 1986.

Molnar, D.P., D. Friedman, and J.S.F. Shih, Lengths of intermediate and deep seismic zones and temperatures in downgoing slabs of lithosphere, Geophys. J. R. Astr. Soc, 56, 41-54, 1979.

Myers, R.E., R.G. Cawthorn, T.S. McCarthy, and C.R. Anhaeusser, Fundamental uniformity in the trace element patterns of the volcanics of the Kaapvaal craton from 3000 to $2100 \mathrm{Ma}$ : evidence for the lithospheric origin of these continental tholeiites, in Geochemistry and Mineralization of Proterozoic Volcanic Suites, pp. 315-326, Blackwell, Oxford, 1984.

Nisbet, E.J., The Young Earth: An Introduction to Archean Geology, Allen and Unwin, Boston, 402 pp., 1987.

Reichenbach, I., and R.R. Parrish, Age of crystalline basement in BC and NWT, Canada, and Co, and Ak, USA, as inferred from U-Pb geochronology of diatremes, Geol. Soc. of Amer., Abs., p. A110, 1988.

Richardson, S.H., J. J. Gurney, A.J. Erlank, and J. W. Harris, Origin of old diamonds in enriched mantle, Nature, 310, 198-202, 1984.

Ringwood, S.E., Constitution and evolution of the mantle, in Kimberlites and Related Rocks, 1, pp. 457-485, Carlton, Blackwell, 1989.

Roy, R.F., A.E. Beck, and Y.S. Touloukian, Thermophysical properties of rocks, in Physical Properties of Rocks and Minerals, edited by C.Y. Ho et al., pp. 409-502, Hemisphere, New York, 1989.

Sacks, S., Subduction geometry and magma genesis, pp. 34-46, in Explosive Volcanism: Inception. Evolution and Hazards, Nat. Acad. Press, Washington, 1984.

Schulze, D.J., Calcium anomalies in the mantle and a subducted metaserpentinite origin for diamonds, Nature, 319, 483-485, 1986.

Schulze, D.J., and H. Helmstaedt, Coesite-sanidine eclogites from kimberlite: products of mantle fractionation or subduction?, J. Geol., 96, 435-443, 1988.

Silver, P.G., and W.W. Chan, Implications for continental structure and evolution from seismic anisotrophy, Nature, 335, 34-39, 1988.

Shackleton, R.M., Dewey, J.F., and B.F. Windley (Eds.), Tectonic evolution of the Himalayas and Tibet, Phil. Trans. R. Soc. Lond, Ser. A., 325 pp., 1988.

Sleep, N.H., M.A. Richards, and B. H. Hager, Onset of mantle plumes in the presence of pre-existing continents, J. Geophys. Res., 93, 7672-7689, 1988.

Smith,W.H.F., H. Staudigel, A.B. Watts, and M.S. Pringle, The Magellan Seamounts: Early Cretaceous record of the South Pacific Isotopic and Thermal Anomaly, Geophys. Res., 94, 10,501-10, 523, 1989.

Takashashi, E., Reconstruction of the Archean Earth, EOS Trans AGU, 71, 967, 1990.

Taylor, S.R., and S.M. McLennan, The Continental Crust: Its Composition and Evolution, Blackwell, Oxford, 312 pp., 1985.

Wang, X., J.G. Liou, and H.K. Mao, Coesite-bearing eclogite from the Dabie mountains in central China, Geology, 17, 1085-1088, 1989.

Watts, A.B., G.D. Kamer, and M.S. Steckler, Lithospheric flexure and the evolution of sedimentary basins, Phil. Trans. Roy. Soc. Lond. A, 305, 249-281, 1982.

Dallas Abbott, L.D.G.O., Palisades, N.Y., 10964

(Received: October 5, 1990;

revised: January 18, 1991; accepted: January 22, 1991) 